\title{
Tomris Uyar'ın “Düşkırıcı” İsimli Öyküsü Üzerine Anlatı Bilimsel Bir İnceleme
} ARŞ. GÖR. GIZZEM ECE GÖNÜL*

Öz

1970'ten 2000'li yılların başına kadar eserleriyle kısa öykü türünün önemli temsilcilerinden olan Tomris Uyar, kaleme aldığı öykülerin temeline toplumu ve bireyi yerleştirir. Döneminin sosyal sorunlarını öykünün içeriğine doğrudan taşıyan yazar, birey olmanın çeşitli hâllerini, varoluşsal sorgulamaları farklı biçimlerle işler. Bunu yaparken edebiyattaki gelişmeleri de göz ardı etmez ve yıldan yıla değişen biçim anlayışı, bakış açısıyla eserlerini oluşturur. Sanatçı, modernist öykü türü ile postmodern teknikleri bir araya getirmiş ve içeriğe uygun bir biçimin örneklerini vermiştir. Bu çalışmada anlatı sanatının güncel olanaklarından yararlanan Uyar'ın "Düşkırıcı" isimli kısa öyküsü, anlatı bilimsel açıdan incelenecek ve öykünün içeriği, biçim özellikleriyle birlikte açımlanacaktır.

Anahtar Sözcükler: Tomris Uyar, “Düşkırıcı”, öykü, inceleme, anlatı bilim.

\section{A NARRATOLOGICAL ANALYSIS ON THE SHORT STORY “DÜŞKIRICI” OF TOMRİS UYAR}

\section{Abstract}

Tomris Uyar, one of the significant representatives of the short story genre with her works written from 1970 until the beginning of the 2000s, places society and individual on the basis of her works. By directly bringing the social problems of the period into the content of the story, the author emphasizes the existential inquisitions and various problematics of individual. Besides, she does not ignore the developments in literature at all, and she forms her works with an understanding of form and perspective changing in years. The author combines the modernist story type with the postmodern techniques, and gives the samples of a form that is suitable for the content. In this study, Uyar's short story "Düşkırıcı" that benefits from the current possibilities of narrative art will be analyzed with a narratological perspective, and the content of the story will be scrutinized together with the features of its form.

Keywords: TomrisUyar, "Düşkırıcı”, short story, review, narratology.

\footnotetext{
* Muğla Sıtkı Koçman Üniversitesi Edebiyat Fakültesi Türk Dili ve Edebiyatı Bölümü, gizemecegonul@gmail.com.
} 


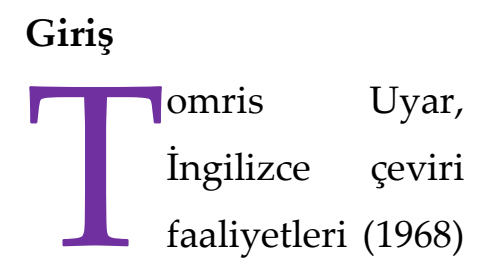

ile yazın sahnesine adımını atar; ardından öykü, deneme, eleştiri yazıları ve günlükleriyle bu sahnede kalıcılığ 1 yakalar. Eserlerini Dost, Papirüs, Yeni Dergi, Soyut gibi dönemin ses getiren, öncü yayın organlarında yayımlar (Necatigil1983: 394). Onun edebiyat dünyasında

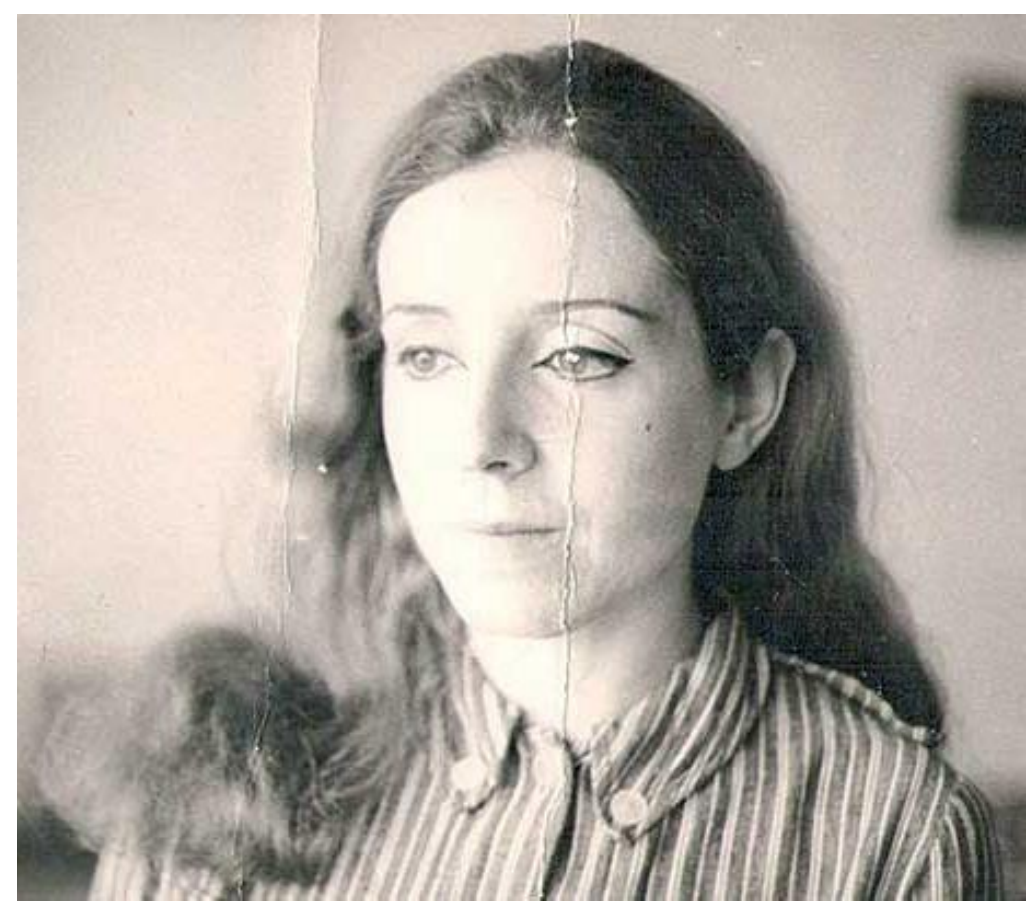
tanınmasına yol açan asıl tür ise öyküdür. 1971 yılında İpek ve Bakır isimli öykü kitabını yayımlayan Uyar'ın, bu tarihten sonra 10'u aşkın öykü kitabında imzası görülür ve yazar, ölümünden bir yıl önce 2002 yılında, öykü yazarlığını noktalar.

Uyar'ın öyküleri geniş bir sosyolojik incelemeye tabi tutulacak derecede toplum ve bireyi içerir. Sosyal alandaki pek çok sorun, bunların bireye yansıma biçimleri, akabinde doğan varoluş sorunu onun öykülerinin temel izleklerini oluşturur. Ancak söz konusu sorunsallar karşısında Uyar'ın tavrı değişkenlik gösterir. İlk yıllarda umutlu bir bakış açısına sahip olan sanatçı, zamanla pozitif bakışını yitirir. Bu bağlamda yazarın öykü serüveni, temel olarak iki döneme ayrılabilir. ${ }^{1}$ Bunlardan ilki 1980'li yıllara kadar şiirsel ve izlenimci tarzda yazdığı öykülerdir. Diğerleri ise çağdaş masalları, postmodern unsurları kullanarak, umuttan ziyade eleştiri barındıran ve bir sorunsal etrafında şekillenen öykülerdir. Tomris Uyar; modernizmin kazanımlarını ve eksiltilerini, değişen toplumsal hayatı, bireyin bu hayatta varoluşunu, kıstırılmışlığını görür ve ilk dönemde bu tabloya ironik, mizahi, şiirsel bir söylemle yaklaşır. İkinci dönemde ise ironi ile mizaha, soyutlama ve eleştiri yöntemlerini de eklemleyerek dönemin panoramasını çizer.

Bu çalışmaya temel olan "Düşkırıcı" isimli öykü, yazarın 1983 yılında yayımladığı Gecegezen Kızlar adlı kitabın son metnidir. Tomris Uyar'ın bu eserindeki her bir öykü, bir masalın ya da masal kahramanının dönüştürülmüş hâlidir. Bu bağlamda işlenen masallar Hansel ile Gratel, Pamuk Prenses ve Yedi Cüceler, Kırmızı Şapkah Kız ile Mavi Sakal, Fareli Köyün

${ }^{1}$ Ayrıntılı bilgi için bkz. Selim İleri, "Türk Öykücülüğ̈̈nün Genel Çizgileri”, Türk Dili Dergisi Türk Öykücülü̆ğu Özel Sayısı, S. 286, b.s.2, Türk Dil Kurumu Yayınları, Ankara, 2008, s. 394.

Ayşegül Nazik, "Tomris Uyar Öykücülüğünde Toplumsal Güncellik ve Biçimsel Arayışlar", Bilkent Üniversitesi Ekonomi ve Sosyal Bilimler Enstitüsü Yayımlanmamış Yüksek Lisans Tezi, Ankara, 2001. 
Kavalcısı, On İki Dansçı Prenses, Uyuyan Güzel, Kül Kedisi, Fesleğenci Kız, Sabırtaşı'nın Şehzadesi ile Çingenesi, Çizmeli Kedi ve Pinokyo'dur. ${ }^{2}$ Eser, önsöz niteliğindeki “Öykülere Girerken” başlıklı bir bölümle açılır. Adı geçen bölüm, eserin amacını ifşa etmesi, yazarın sesini duyurma arzusuyla kaleme alınması sebebiyle bir manifesto olarak da okunabilir. Pertev Naili Boratav'ın "Halk masallarının kişileri, belli bir tarih anında, belli bir yerde yaşamış olan bir topluluğun belli fertleri değil de bir padişah, bir tüccar, bir kocakarı gibi yersiz, adsız kişilerdir" (Uyar 2016: 7) şeklindeki halk masallarının kişilerine dair tespiti³, manifestonun ilk sözünü oluşturur ve Uyar'ın adı geçen eserdeki öyküleri bu saptamanın âdeta işlevselleştirilmiş hâlidir. Yazar, amacının masal kişilerini birey olarak ele almak, söz konusu kahramanların 20. yüzyıldaki muhtemel izdüşümlerini göstermek olduğunu ifade eder. Masal kahramanlarını, özellikle kadın karakterleri, onlara biçilen kalıptan çıkarmaya çalışan Uyar'ın bu öyküleri; bireyin kendini, mutluluğu ve özgürlüğü arama tutkusunu içerir. Kahramanları farklı bir zaman ve biçimde yaşatma niyetinde olduğunu söyleyen yazar, onları düşleriyle bulunduğu çağa taşıdığını ifade eder ve bir yazar olarak kendisini de masal kahramanı sınıfına yerleştirir (Uyar 2016: 8). Yazarın bahsi geçen bölümde; “Özellikle kadınlar, eski masallarda önlerine değer diye sürülen 'şehzade ile evlenmek', 'zengin olmak', 'sınıf atlamak' gibi özlemleri çoktan bir yana itmişlerdi" (7) sözleriyle belirttiği üzere bu öyküleri kaleme alış amacı, eski anlatılardaki kişilerin gerçekliğinin yeni toplumsal hayata uygun düşmemesidir.

Hürlük ve benlik temlerinin işlendiği öykülerin odak karakterleri genellikle kadınlardır ve kitaptaki on öyküden beşi, bir kadına ithaf edilmiştir. Özgür olma, birey olma sorununu daha çok kadınlar üzerinden kuran yazar, bu yönüyle de temel toplumsal bir meseleye değinir. Tıpkı masal kahramanlarının kalıplaştırılması, onlara verilen rollerin, yüklenen anlamların hiç değişmemesi gibi kadınların ya da genel olarak bireylerin de benzer biçimde kuşatılmışlığı, Uyar'ın bu öykülerdeki ana sorunsalı oluşturur. "Ya da" diyorum çünkü öykülerde nicel olarak daha çok kadın karakterlerin kıstırılmışlığı yer alsa da erkek karakterlerde de benzer sorunlarla karşılaşılır. Ana karakterinin cinsiyeti bilinmeyen "Düşkırıcı" isimli öykü, "Gül'e" ithafıyla başlasa da kurmaca kişinin erkek olduğuna dair kimi işaretleri içerir ve bu anlamda parça, Gecegezen Kızlar'da rastlanılan erkek karakter odağında kurulmuş nadir öykülerdendir. Ne var ki burada önemli olan cinsiyet meselesi değil, bireyin özgürlük, kuşatılmışlık gibi sorunlarla nasıl sarmalandığıdır. Küçük hacimli bu öykü, bahsi geçen sorgulamaları yoğun bir şekilde yaparak kazandığı modernist öz ve yapıyla birlikte postmodern anlatı tekniklerini de ustaca kullanabilmiştir. Anlatının kendisi

\footnotetext{
${ }^{2}$ Ayrıntılı bilgi için bkz. Tomris Uyar, Gecegezen Kızlar, Yapı Kredi Yayınları, İstanbul, 2016, s. 7-8.

${ }^{3}$ Belirtmekte fayda var ki Pertev Naili Boratav'ın bu tespiti, Zaman Zaman İçinde isimli, tekerleme ve masalları incelediği eserinin "Giriş" bölümünün ilk cümlesidir. Ayrıntılı bilgi için bkz. Pertev Naili Boratav, Zaman Zaman İçinde, Adam Yayınları, İstanbul, 1992, s. 13.
} 
ve anlatısallığı oluşturan tekniğin bir arada açımlanması ise anlatı bilim perspektifini gerektirmektedir.

Kendi varlığına dair bir im arayışı içinde olan

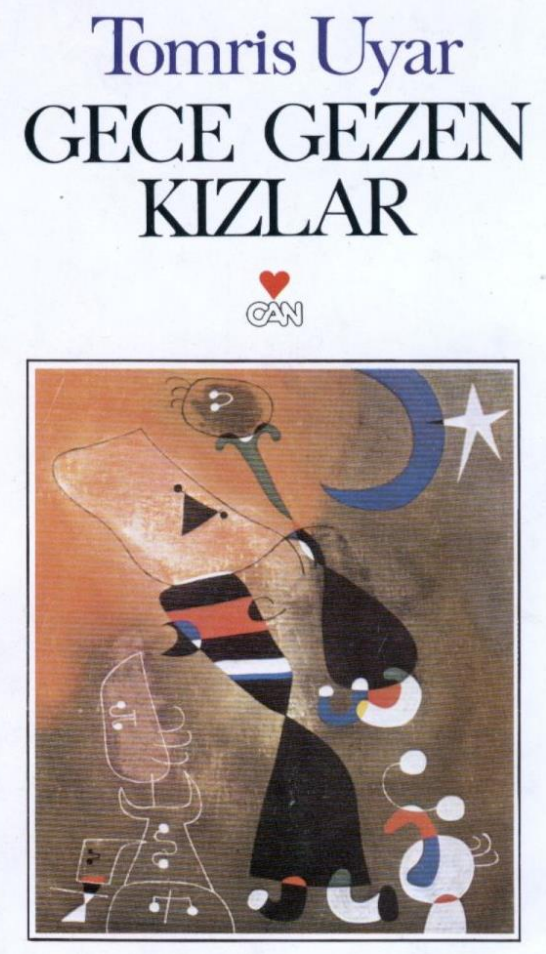
karakterin benliğinden uzaklaşmasının hikâyesi olan "Düşkırıcı", kentle öğütülen bireyin sancılarını işler. Bu sanc1, ataerkil düzenden ileri gelmektedir çünkü karakterin karşı çıkamadığı ve tabi olduğu bireyler erkekler iken bu durumdan kurtuluş umudu, annede, bir kadın figürde aranacaktır. Öykü kişisi, başkalarına -baba, kuklacı, Efendi olarak anılır- itaat etmesi sebebiyle hiçbir zaman benliğini görememiş, var olamamıştır. Öyle ki bu durumun bir temsili olarak öyküde "Efendi" nin baş harfi her zaman büyük puntolarla yazılıdır. Anlatı, karakterin bu durumun farkında olduğu zamana odaklanır ve onun bunalımını doğrudan yansitır. Bunalım hâlinin son buluşu ise intihar vesilesiyle gerçekleşir. Böylece var olamama sorunu, yoklukla tamamlanir.

\section{“Düşkırıcı”nın Anlatı Bilim Işı̆̆ında Çözümlenmesi}

Çalışmanın yöntemi olan anlatı bilim bileşenleri, Oktay Yivli'nin Kısa Öyküde Yöntem ${ }^{4}$ isimli kitabından hareketle oluşturulmuştur. Bu bağlamda anlatı tür, düzen, anlatıcı, odaklanma, anlatım yapısı, zaman ve anlatı birimleri olmak üzere yedi başlık etrafında incelenecektir.

Tomris Uyar'ın “Düşkırıcı” isimli öyküsü, karakterin zihnine odaklanıp iç çatışmalarını, sorgulamalarını birincil kaynaktan sunması ve yine karakterin yaşam öyküsünün, ayna tutulan zihnin geçmiş ve şimdi arasında ördüğü ağ üzerinden verilmesi sebebiyle dramatik bir öyküdür. Kişiye ait iç sorgulamaların bir bohça gibi açılmasında etkili olan unsurlardan birinin zamanda geriye dönüşler olduğu söylenebilir. Böylece dramatik öykünün özünde var olan çatışmanın izleri, hem bireyin sorgulamaları hem de zamanın metceziri üzerinden sürülebilir. Öykü isminin de göndermede bulunduğu üzere "Düşkırıcı", öykü kişisidir ve düşlerini yaşamaktan ziyade onları kuramamış, bulamamış, düşleri kırılmış bir karakterdir. Geçmişini bir "efendi”ye adayarak köleleşen karakter, ne öykünün ne de kendi hayatının eyleyeni olabilmiştir. $\mathrm{O}$, kim olduğundan ne iş yapacağına kadar bireyi var

${ }^{4}$ Oktay Yivli, Kısa Öyküde Yöntem: Cemil Süleyman Uygulaması, Çizgi Kitabevi, Konya, 2015. 
eden tüm düzlemlerden aridir ve farkındalığının etkisiyle varoluş problemi yaşamaktadır. Anlatı, "Düşkırıcı"nın "şimdisi"ni, "öncesi"ni ve nihayetinde bir düğüm atar gibi "şimdi"ye geri dönüşlerini, gerek iç monolog tekniğine gerekse de dolaylı aktarıma başvurarak sunar. Sorgulamanın iç monolog şeklinde verildiği; “"Anacığım desene, tahta oğlun bir kukla olmuş, bir canalıcı, bir düşkırıcı. İşi bitik'” (Uyar 2016: 90) ifadesiyle birlikte bir sabahçı kahvesinde günü aydıran karakterin geçmişi de dışöyküsel anlatıcı tarafından şu şekilde sunulur:

“Kente geldiği geceyi, geceyi geçirdiği sabahçı kahvesini anımsıyor belli belirsiz.

[...] Sonra Kuklacı'ya satılışını. Babasının doğru dürüst yontamadığı ayaklarına Efendisi'nin bu halis kösele, kırmızı çizmeleri geçirişini. Kendi köyünden başladı.

[...]Otel lobilerini, diskotekleri, bankaları.[...] Hepsini kattı, kapattı, hızla yol açtı Efendisi'ne" (89).

Öykünün giriş paragrafı, bir sabahçı kahvesinin betimlemesiyle başlar ve mekânın içindeki çeşitli eşyaların bir sayfayı aşan ayrıntılı tasviriyle devam eder. Giriş bölümünde yoğun betimlemelerle karşılaşan okur, öykü söylemi devam ederken olayların akmadığına tanık olur. Kâğıt üzerinde bir tablo oluşturulmuş ve öykünün başladığı, geçtiği mekân üzerinden hem bir atmosfer yaratma hem de öykü kişisini tanıtma çabasına girilmiştir. Mekânın iki farklı yüzle, işlevsel olarak kullanıldığı anlatı, giriş kısmında uzun tasvirleri barındırması ve herhangi bir eylem içermemesi sebebiyle durağan başlangıçla açılır. Tasvirlerin son bulduğu noktada karakter, gördüğü her nesneden hareketle geçmişine döner. Bu sebeple kahvehanedeki nesneler, karakterin tanıtılmasında önemli bir işlev üstlenir.

Anlatının ikinci sayfasından itibaren karakterin geçmişi, kimliği öykü kişisinin odağında, iç odaklanma aracılığıyla sunulur. Öykünün sonuna kadar farklı kişilerin ismi anılsa da anlatı, tek bir karakteri temel aldığı, yalnızca onun zihnine girebildiği ve iç/dış dünyayı tamamen karakterin gözünden aktardığı için sabit odaklanmayla kurulur. Olayları idrak eden zihin karakterdir ve dolayısıyla öykünün zihni de yine karakterin kendisidir. Anlatının giriş cümlesi olan; "Gözlerini açtı: bir sabahçı kahvesi" (87) ifadesinden hemen sonra başlayan ve yukarıda da bahsi geçen betimlemeler, âdeta bu gözün kamera lensi olarak kullanılıp onun odağından aktarılmasıyla verilir. "Duvarları tarayan", "masalara bakan" bu gözün ta kendisidir. Devam eden satırlarda aynı göz, malikine çevrilir ve gördüğü nesnelerden hareketle öykü kişisinin hem mazisinin hem hâlinin; "Kesin bir süreklilikte birleşemeyen bu küçük süreklilik parçacıkları hiçbir ipucu vermiyor. Kahve iyice soğuk. Ayaklarını kaldırıp sobaya dayıyor. Gıcır gıcır çizmelerini gözden geçiriyor. Yol almaktan eskimişler azıcık, kirlenmişler" (88) sözleriyle açığa vurulmasını sağlar. "Çizme"nin bir sembol olduğu hemen arkasından anılan "yol" kavramı ile açıklığa kavuşur. Her ne kadar "gicır gicır" olsa da eskiyen, kirlenen çizmeler uzun yollar katedildiğinin bir 
işaretçisidir. Öte yandan anlatının bu noktasında alıntılanan bir tekerleme de yoldan gelinip yola çıkıldığının hatta yolculuk hâlinin devam ettiğinin dolayısıyla kimlik arayışında olunduğunun ifadesidir:

“Ettim edemedim, bir sanat tutayım dedim.

Amma velakin ne olsam?

Kayyum olsam kandilleri yakmalı

Mezin olsam minareye çıkmalı

Münsür olsam el hatırı yakmalı

Hâkim olsam şer'isine kıyamam.

Bakkal olsam kaldıramam kantarı

Kasap olsam sallayamam satırı

Nalbant olsam nallayamam katırı

Berber olsam eşin dostun hatırı" (88).

Anlatının, iç monolog tekniği ile kurulmuş bu satırları "Ne Olsam?"5isimli tekerlemeden alınmıştır. Boratav'ın tespitine göre bu tekerleme, doğrudan halk şairlerinden alınan parçaları içerir (Boratav 1992: 39). Ancak metinde tekerlemenin devamı şu şekilde bir dönüştürmeyle sunulur:

"Ah ne olsam ne olsam...

Öcalıcı Derviş olsam

Bebe kanında yıkansam

Arap olsam, iki kuş bir tüfekli

Taze oğlanları düşte aldatsam

$[\ldots]$

Ah ne olsam ne olsam

Ne olsam da ter dökmeden kazansam..." (Uyar 2016: 88).

İç monolog örneği olan bu satırlar, birincil ağızdan aktarılmasıyla öykü kişisinin bir nevi kendini tanımlamasıdır. Bir masal tekerlemesi olduğu tespit edilen parçaya eklemeler yapılmış ve tekerleme uzatılmıştır. Elbette ki "masal anlatıcı, istediği -ve kurabildiği- kadar halka aracılığıyla diziyi uzat[abilir] ya da kısalt[abilir]."(Boratav 2000: 10) Böylece anonim halk edebiyatı ürünlerinden olan tekerleme ile öykü formunun birleştirilmesi, türlerarasılığın; iki metnin bir arada kullanımı, içeriksel olarak birbirini tamamlaması metinlerarasılığın varlığını gösterir. Buradan hareketle anlatının masal izleri taşıdığını yalnızca olay ya da kişi anıştırmaları aracılığıyla değil, formdaki değişim üzerinden de söylemek mümkündür. Tekerlemenin kullanımı ile birlikte tüm metnin bir masal anlatısı görünümüne büründüğü, böylece "masal-öykü" olduğu söylenebilir. Öykünün düşsel bir zemin teşkil etmesi, olayların adı bilinmeyen büyük bir kentte geçmesi ve bu kente yine adı

${ }^{5}$ Bkz. Pertev Naili Boratav, Zaman Zaman İçinde, Adam Yayınları, İstanbul, 1992, s. 81. 
bilinmeyen başka bir yerden yola düşülerek gelinmesi masal formunun varlığını açıkça gösterir.

Anlatı yalnızca tekerlemeye yer vermesi nedeniyle değil, çeşitli masallara göndermeler yapmasıyla da metinlerarası bir özellik taşır. Öyle ki efendisinin kendisine bir çizme verişi ya da karakterin ayaklarının yontulması; Kuklacı'ya satılışı; “fare oldu kediyi üttü” (Uyar 2016: 89); “Geleneksel yara-almaz bacaklarıyla hızla yol aldı, yalnız arasına, ağacın dişil damarlarından geçen soğuk işleyebiliyor ahşap yüreğine” (89); “'tahta oğlun bir kukla olmuş'” (90) ifadeleri Çizmeli Kedi ve Pinokyo masallarına yapılan açık göndermelerdir. Adı geçen masalların içeriğine bakıldığında efendi-köle diyalektiği göze çarpmaktadır. Pinokyo'yu oluşturan ustası Gepetto onun bir nevi babası,

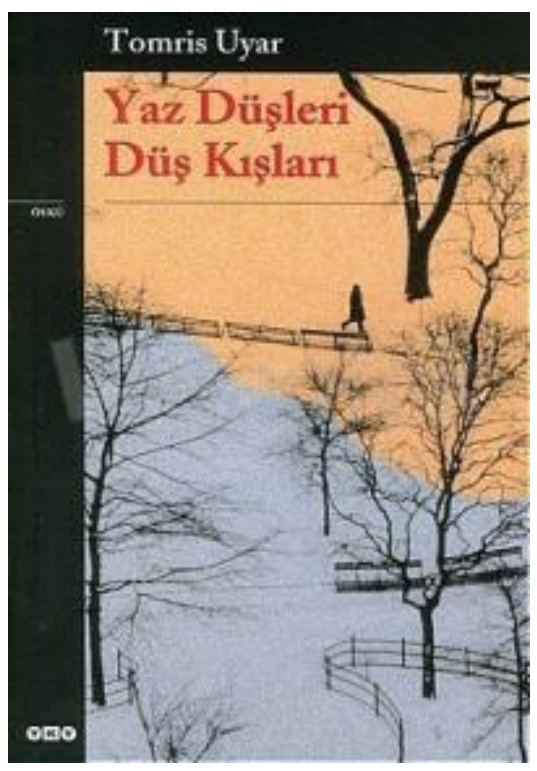
efendisi iken Çizmeli Kedi'nin efendisi de bir babanın üç oğlundan en küçük olanı ve Çizmeli Kedi'nin isteği doğrultusunda ona bir çuval ve bir çizme bağışlayanıdır. Çizmeli Kedi, elde ettiği çuval ve çizme aracılığıyla ülkenin kralına çeşitli hediyeler götürür, kıvrak zekâsıyla kralın kızı ile efendisini evlendirir, kendisi de bir devi fare olmaya ikna ederek onu yutar ve sefa içinde bir ömür sürer. Ancak inceleme nesnesi, söz konusu masal ile birkaç noktada ayrılır. Masalda kedi, efendisine hükmediyorken, efendisinin efendisi iken anlatıdaki karakter, efendisinin hâkimiyetinden sıyrılamamıştır. Masalda Çizmeli Kedi, devin fareye dönüşmesini sağlayıp onu yutarak üstünlük sağlar. Öyküde ise "fare olup kediyi ütme" konu edilir. Dikkat edilmesi gereken nokta her iki metinde de -masalda ve öyküde- güçsüz olanın güçlüye galip geldiğidir. Böylece iki tür arasında paralellik yakalanmış olur, yalnızca eyleyenler yer değiştirmiştir. Sahibi tarafından çizme verilip varlığını ona adayan Çizmeli Kedi, ustası Gepetto'nun sözünden çıkmamayı hazin olaylarla öğrenen Pinokyo gibi anlatı karakteri de efendisinin -Kadir Ağabey'in- kulu olmuş, köyünden, benliğinden başlayarak birlikte yaşadıkları kente kadar yaşamının tamamını ona adamıştır. Böylece ataerkil bir düzende var olma sıkıntısı çeken bireyin kendilikten uzaklaşması, bir başkası olmadan yer edinememesi, iplerin bir diğerinin elinde olduğu kuklamsı bir hayat sürmesi öykü kişisini silikleştirmiş, onu hastalıklı bir bünye sahibi yapmıştır. Üstelik kişi, tekerleme vasıtasıyla sıraladığı meslek gruplarına dâhil olamayarak, kendine bir düş kuramayarak bir kez daha yenilmiştir.

“Düşkırıcı"nın hikâyesi dışöyküsel anlatıcı tarafından aktarılır ve anlatıcının bilgisi ise kendini "canalıcı" olarak tanımlayan karakterle sinırlıdır. Anlatı boyunca "Efendi" Kadir Ağabey ve onun oğlu Özgür, Kuklacı, karakterin annesinin isimleri geçse de anlatıcı tüm 
öykü kişileri hakkında önceden bilgiyle donatılmış değildir. Kaldı ki odağa alınan karakterle ilgili her noktayı bilmemektedir. O, yalnızca subjektif ve olay zamanlarına dair kısmi bilgiye sahiptir. Subjektif zamanın esas olduğu noktalarda anlatıcı, odağın bilincine girer ve olanları birlikte yaşamışlar hissi uyandıracak şekilde aktarır. Esasen öykü zamanında sabahın ilk 1şıklarında bir kahvede oturan karakter, psikolojik zaman olarak şimdiden ötede, geçmiştedir. "Söylem yetkilisi"nin' öykü kişisinin geçmişini anlattı̆̆ı satırlar, aynı zamanda karakterin zamanda geriye dönüşleri, hatıraları, geçtiği merhaleleri içerir. Buna göre köyden bir gece vakti ismi bilinmeyen bir kente gelen "Düşkırıcı", Kuklacı'ya satılır. "Kuklacı" söylemiyle anılanın, babaya gönderme olduğu; "babasının doğru dürüst yontamadığ1 ayakları" (89) ifadesinde açıcça görülür. Kentte bir efendiye tabi olan ve özel adı bilinmeyen karakter, kendisini ona bir çizme bağışlayan efendisine adar, esrardan silah satıcılığına kadar pek çok karanlık işte çalışır. Okuyucunun karakterin yaşam öyküsüne ortak olduğu kısımlardan sonra ise anlatının şimdisine dönülür ve öykü kişisinin "tertemiz bir düş arayışı" içinde olduğu belirtilir. Bu durumun bir işaretçisi olarak kahveden sokağa çıkılır ancak umutsuzluğa düçar olan karakterin intihar sahnesi sezdirilir. Söz konusu sezgiyi sağlamada hem bir gazete haberinin montajlanması hem de öykünün kapanışını oluşturan; “Efendisi'nin ayak sesleri yaklaşıyor, kulağının dibinde duruyor. Önce sağ çizmesini çıarıyor. Su, buz gibi" (90) cümleleri etkilidir. "Fatih'te bir bar fedaisi kimseye kötülük etmek istemediğini ileri sürerek intihar etti" başlıklı haber ise bu cümlelerin hemen öncesine yerleştirilmiştir. Sayfanın ortasına, kenarları çerçevelenmiş bir şekilde montajlanan bu parçanın haber olduğuna dair ilk bakışta nesnel bir bilgi olmasa da alıntılama olduğu açıtır. Bahsi geçen habere Milliyet gazetesinin arşivinde 02.10.1981 tarihli gazetenin yedinci sayfasında rastlanılır:

\footnotetext{
${ }^{6}$ Oktay Yivli, anlatanı, anlatıcı sesi, "söylem yetkilisi” ismiyle kavramsallaştırır. Ayrıntılı bilgi için bkz. Oktay Yivli, “Ethem Baran'ın "Emanet Gölgeler Defteri”nde Temel Sorunsallar", Yeni Türk Edebiyatı Dergisi, S. 14, Ekim 2016, s. 165.
} 
Muharrem Koc, adh 36 yasin.

Jaki fedai dún gece saat 02.00 'de Esrar Dede Sokak'ta tabanca. syla havaya do el ates ettikten sonra, bir el de kafasina sikarak canina kaymıstur. Muharrem Kov'un ozerinden, intihar etme. den once yazdiga bir pusula cik. migtir. Uyugturucu kullandiga One sirulen Koc, pusulada şun. One surulen Koc, pusulada sun.
lari yazmigtur: ari yazmigtur:

"Hasta beynimle daha fazla

yasayamazdim. Ne yapsam iyi-

lesemeyeceḱtimi biliyordum.

Kimseye kötulak yaprrak iste.

medim. Hayatıma bu sekilde

son vermenin iyi olacaǵna karar

verdim."

\section{Şekil 1.a.}

Öykünün sonuna montaj tekniği ile iliştirilen bir haber kesitiyle metinlerarası ve aynı zamanda türlerarası bir ilişki yaratılır. Ancak şunu belirtmekte fayda var ki bu montajda içeriğe sadık kalınırken biçimsel olarak kimi düzenlemelere gidilmiş ve haber, gazete kupürü görüntüsünden şu şekilde uzaklaştırılmıştır:

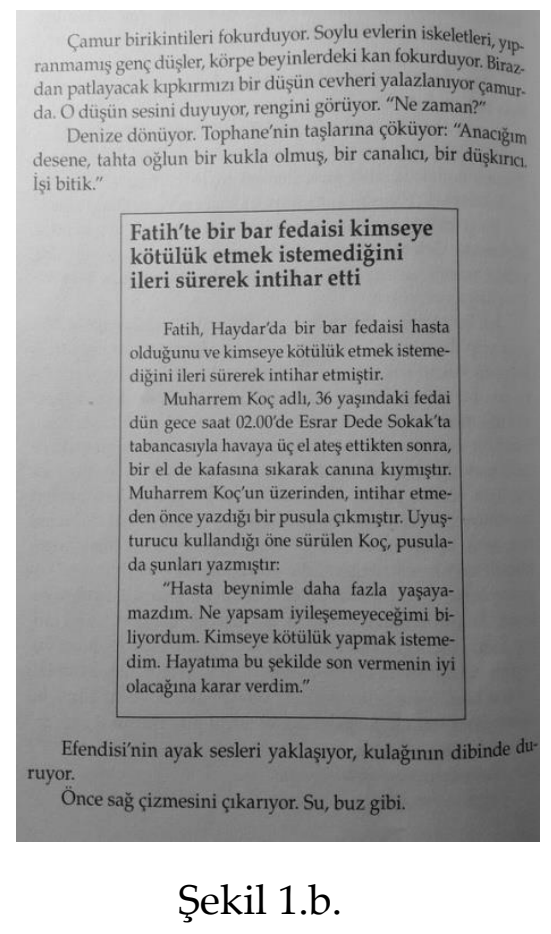

Yukarıdaki parçanın kullanılmasıyla gerçeklik ve kurmaca, aynı düzlemde buluşur. Bu buluşmanın bir çıktısı da öykünün aktüel zamanı işaret etmesidir. 1983 yılında yayımlanan Gecegezen Kızlar isimli kitabın incelenen öyküsü, 1981 tarihli bir gazete haberini taşımasıyla nesnel zamanı öyküye dâhil eder ve metinde girift bir zaman evreni yaratılır. Adı geçen 
montaj, aynı zamanda öykünün aydınlanma anını sağlayıcı bir unsurdur. Öykünün başından itibaren anlatılanlar bu montaj aracılığıyla somut bir görünüm, geçerlik kazanır. Anlatının başından neredeyse sonuna kadar ismi bilinmeyen karakterin kimliğinin bir göstergesi olarak da okunabilecek bu haber sayesinde öykü kişisinin 36 yaşında, bir barda güvenlik görevlisi olan Muharrem Koç olduğu öğrenilir. Ancak Koç, kafasına bir el ateş etme suretiyle intihar ederken "Düşkırıcı", "canalıcı" olarak tanımlanan karakterin, "önce sağ çizmesini çıkarmak" suretiyle âdeta suya girdiği, varlığını suya bıraktığı hissi verilir ve bir boğ(ul)ma atmosferi yaratılır. Öyle ki öykü sesinin son tınısı olan “Su, buz gibi” söylemi bu seziyi kuvvetlendiren bir parçadır. Montajlanan parça ve öykü arasında bir korelasyon olduğunu kabul etmek yerindedir. Ancak bu durumda yorum güzergâhının çatallandığını da göz ardı etmemek gerekir. Şöyle ki haberden hareketle öykü kaleme alınabileceği, haberin öyküsü yazılabileceği gibi öykünün içeriğine uygun bir haber de seçilmiş olabilir ve bu sebeple iki öge de birbirlerini besleyen, birbirlerine dayanan yapılardır. Böylece ikilinin arasında pozitif bir korelasyon olduğu ilk bakışta göze çarpar. Elbette ki bu ayrım, “öykü kişisi kim ve nasıl intihar ediyor" sorularını cevaplamada yetersiz kalır. Montajlanan parçaya gelinceye kadar karakter, dışarı çıkmış ve deniz kenarına gelmiştir. Bu parça göz ardı edilerek okunduğunda kendini suya bırakan bir kişi görüntüsüyle karşılaşan okur, haber devreye girdiğinde ikiliğe düşer ve bir soru daha açığa çıkar: "Muharrem Koç kimdir?" Bu noktada yine öykü ve haberin pozitif korelasyonuna sığınılabilir. Hikâye arkında çizmesini çıkaran karakter suya girer ve sonrasında haberde yer aldığ kafasına bir el ateş ederek intiharını gerçekleştirir. Bu durumda okur, karakterin sonunu öykünün sonundan değil de montajlanan parçadan öğrenir. Buradan hareketle bar fedaisi olan Muharrem Koç ile güne bir sabahçı kahvesinde başlayan, varlığını efendisinde yok eden, kendisini "canalıcı”, “düşkırıcı” olarak tanımlayan karakter aynı kişidir. Biri diğerinin kurmaca dünyadaki karşılığı, lengüistik figürüdür. Diğer durumda ise iki kişi benzer yaşam öyküsüne sahip iki farklı karakterdir ve çağrışım yoluyla bu tip kişiler aynı çatı altına toplanmıştır. Muharrem Koç'un silah ile intiharı, kurmaca düzlemde suya girme olarak yorumlanmış olabilir. Varsayım ne olursa olsun öykünün sonu umutsuz-acıklı son olmaktan kurtulamamıştır.

Bir barda koruma görevlisi olan Muharrem Koç'u intihara sürükleyen nedenler, öyküde bu hâliyle sembol değerlerle sıralanırken Koç'un yazdığı not da bu durumu hedef gösterir: "Hasta beynimle daha fazla yaşayamazdım. Ne yapsam iyileşemeyeceğimi biliyordum. Kimseye kötülük yapmak istemedim. Hayatıma bu şekilde son vermenin iyi olacağına karar verdim" (90) Hastalığa birey olmaktan uzaklaşma, kendi olamama, başka birine sınırsız itaat gibi nedenler yol açar. Muharrem Koç ya da -öykü kişisi o değilse"Düşalıcı", hastalıklarıyla baş edemeyip tedavi yöntemini hayatlarını sonlandırma olarak 
belirlemişlerdir. Böylece yaşamları boyunca efendiye, ustaya, babaya bağlı karakterler özgürlüklerini yitirmiş ve belki de bu son hamleyle ilk defa hayatlarının eyleyeni olmuşlardır.

\section{Çizmeli Kedi ve Pinokyo}

kadar öyküyü kuran cephede yer almasa da inceleme nesnesi, anıştırma yoluyla başka masallardan da izler taşır. Bunlardan biri, karakterin itaat alanından kurtuluşunu "kuleden saçlarını sarkıtmak" (89) suretiyle kendisini refaha kavuşturacak annesi ile Rapunzel arasında bağ kurmasinda görülür. Bu görüntüyü bölen realite ise “Kar[in], onun kentin ormanina gelirken yola serptiği ekmek kırıntılarını savur[masıdır]" (89). Ev ve orman, dışarısı, vardığı nokta arasında geldiği yolu hatırlamak adına yola ekmek kırıntıları bırakması ise Hansel ve Gratel kardeşlerin hikâyesini işleyen anlatıyı çağrıştırır.

Örneklerde de görüldüğü üzere anlatı; betimlemeler, iç monolog, montaj gibi tekniklerle zenginleştirilmiştir. Ancak tüm bunlar, öyküleme yapısının gidişatını bozmaz. Öyküleme yapısı hatıralar yoluyla zamanda geriye dönüşleri içerse de anlatı çizgisi değişmez, olaylar kronolojik olarak birbirini takip eder ve zaman dizinsel bir yapı içinde günün bir bölümü aktarılır.

İzlenimlerin, duyguların, düşüncelerin anında öykülemeye tabi tutulmasıyla öyküleme zamanı, eş zamanlılık özelliği gösterir. Anlatının yalnızca ilk kısmında kullanılan "gözlerini açtı" söylemi biçimsel bir eş zamanlılık izlenimi verse de anlatının devamındaki "Ayaklarını kaldırıp sobaya dayıyor” (88), “İçli bir türkü duyuyor ansızın. Kayıyor. Kapıyı açıp dışarıya çıkıyor" (89), "Denize dönüyor, Tophane'nin taşlarına çöküyor. [...] Önce sağ çizmesini çıkarıyor" (90) ifadeleri, hikâyeyi kuran olayların gerçekleştikleri anda söylemleştirildiğini, öyküleme zamanının doğrudan eş zamanlı biçimde oluşturulduğunu belirtir.

Anlatı birimlerine bakıldığında ilk bileşenin bir tablo olduğu görülür. Yoğun betimlemelerle açılan öykü, durgun bir ritimle başlar. Anlatı birimlerinin öyküye ritim kazandırdığı düşünüldüğünde metnin açılış temposunun “adagio"ya yakın olduğu söylenebilir. Bu sebeple anlatının konumlandığı̆, uzayıp gittiği düzlem, dikeydir. 
Betimlemelerin arasından bir fotoğraf karesi ile göz göze gelen karakterin; “'Aaa! Kadir ağabey değil mi o?'” (87) diyen sesi duyulur. Bu, araya iç monolog tekniğiyle sıkıştırılmış bir dramatik sahnedir. Devamındaki satırlarda tablo ön planda olsa da karakterin iç sesinin; “'Ne zaman?'” (88) sorusuyla duyulması, anlatıya küçük bir dramatik sahne eklendiğini, tablo ve sahnelerin peş peşe gelerek ritmik, canlı bir yapı oluşturduğunu gösterir. Öykü öznesinin zaman sorgulamasını "anlatıcının marifetiyle okuru doğrudan eylemin içine çek[erek] düzenle[nen]" (Yivli 2015: 97) anlatımlı sahne devralıyor gibi gözükse de çok geçmeden kahve tablosuna geri dönülür. Araya giren ufak sahneler haricinde bir sayfayı aşan betimleme kısmında öyküleme devam eder ancak hikâye yerinde sayar, ta ki söylem âdeta bir takip 1şı̆̆1 gibi karaktere yönelinceye dek. Gözlerini açmak, bakmak, görmek dışında karakterin ilk eylemi, “ayaklarını sobaya dayamak”tır (88). Böylece tablo yerini anlatımlı bir sahneye bırakır. Bu kısa hareketlenmeden sonra tekerleme bölümüyle birlikte karakterin iç monoloğu görülür. Tekerleme italik olarak yazılması, birinci şahıs anlatımıyla düzenlenmesi ve karakterin iç sorgulamalarını taşıması nedeniyle iç monologdur ve dolayısıyla dramatik sahneyi kurmaktadır. Karakterin yaşam öyküsünün sunulduğu kente ilk gelişi, hemşehrileriyle kolektif bir yaşam sürmesi ve onlarla mitinge gidişlerini, uluyuşlarını, ant içişlerini hatırladığı sahneler anlatımlı özellik gösterir. Bu anlatımlı sahne aracılığılla karakterin kente sonradan geldiği, yabancı ve yolcu olduğu vurgusunu kuvvetlendiren bir sabahçı kahvesine sığındığı, "uluyuş" simgesiyle milliyetçi cephede yer aldığı, her göçmenin vardığı yerde hemşehrileriyle birlik oluşu gibi karakterin kolektif bilince sahip olduğu bilgilerine ulaşılır. Sabahçı kahvesi, anlatının açılışını oluşturduğu gibi karakterin kentle, yeni yaşamıyla tanışmasını da simgeler. Söz konusu anlatımlı sahne aracılığıyla öğrenildiği üzere bu noktadan sonra karakterin dönüşümü başlayacaktır. Anlatıda da işaret edildiği gibi girişteki kahvenin, kentte gecenin geçirildiği ilk mekân olma ihtimali yüksektir. Dolayısıyla bu sahneler, karakterin yolculuğunu yine onun sorgulamaları vasıtasıyla veren parçalardır. Tüm sorgulamalara sebebiyet veren kahve, hem genel olarak taşıdığı yol sembolizasyonu hem de öyküde kişisel bir yolculuğa zemin oluşturması bakımından oldukça önemlidir. Karakter, yine bu kahvede vardığı noktayı, dönüşümünü, efendiye sahip olup varlığını ona verişini kendisine itiraf eder.

Öykü kişisinin efendisi için yerine getirdiği görevlerin anlatımı ise özetleme şeklinde sunulur. "Esrar sardı, dumanını gizledi; silah sattı, ölenleri gözledi; umut sattı, umutsuzluk besledi" (89) eylemleri birçok kez yapılsa da indirgeme yöntemiyle biricik gibi gösterilir. Karakterin yaşamının anlatıldığı sahneler genel olarak özetlenmiş, her bilgiye yer verilmeyerek olaylar seyreltilmiş, karakterin öyküleme zamanında içinde bulunduğu duruma dair ipucu veren parçalar aktarılmıştır. Dramatik sahnenin bir başka kurgusu, tekerlemenin yazar tarafından geliştirilmiş bir varyantına yer vererek devam eder: 
"Polis olsam sanıkları dövemem

Kahya olsam şoförleri kovamam

Memur olsam kimseleri savamam

Savcı olsam insanları sevemem

Ah ne yapsam ne yapsam

Ne yapsam da bu kente tertemiz bir düş bulsam..." (90).

Daha önce de bahsi geçen "Ne Olsam?" isimli masal tekerlemesi yazar tarafından dönüştürülmüştür. Tekerlemeye yeni meslek grupları eklenmiş, son iki satırda da tekerleme, öykü ile ilişkili hâle getirilmiştir. Buradan hareketle yazarın tekerleme mantığını, yapısını ve cümle üslubunu kullandığı, geleneksel yapıyı modernleştirdiği söylenebilir. Bu tür aracılığıyla karakterin iç monoloğu devam ederken karakterin içinde bulunduğu durumu iletme işi, anlatımlı sahneye devredilir ve atmosfer yaratımı tamamlanır: "Çamur birikintileri fokurduyor. Soylu evlerin iskeletleri, yıpranmamış genç düşler, körpe beyinlerdeki kan fokurduyor. Birazdan patlayacak kıpkırmızı düşün cevheri yalazlanıyor çamurda. O düşün sesini duyuyor, rengini görüyor. 'Ne zaman?'” (90). Bu soruyla öykünün ilk sayfalarında da karşılaşılır. Karakterin derin bir sorgulama içinde olduğu, zaman üzerinden de gösterilir ve böylece dönüşüm çemberi bir kez daha anıştırılır çünkü ikinci kez tekrarlanan soru, öykünün de karakterin de sona yaklaştığının işaretçisidir. Tırnak işareti içindeki soru, iç monoloğun sürdüğüne dair bir imdir ve monolog; “'Anacığım desene, tahta oğlun bir kukla olmuş, bir canalıcı, bir düşkırıcı. İşi bitik'”' (90) itirafıyla son bulur. Örneklerde de görüldüğü üzere sahnelerde öyküleme zamanı ile hikâye zamanı birbirine eştir ve bu sebeple anlatı ile okur aynı düzlemde bir araya gelir. Böylece sahneler yardımıyla özdeşleşme gerçekleşir. Öykünün sonu ise yarım bir sahne ile kapanır ve bu kez karakterin sesi tırnak içine alınmadan duyulur: "Su, buz gibi" (90). Anlatının son cümlesi olan ses, anlatıcıya ait gibi dursa da anlatıcının karakterin yaşadığı deneyime dâhil olamayacağı göz önünde bulundurulduğunda, üstelik anlatıcının bahsi geçen cümleyi dolaysız aktardığına dikkat edildiğinde bu deneyimi karakterin tek başına yaşadığı söylenebilir. Öyleyse denebilir ki anlatıcının sesi ile karakterin sesi birbirine karışmış; anlatıcının söylemi içinde karakterin sesinin duyulmasına izin verilmiş, serbest dolaylı anlatımın bir örneği sunulmuştur.

Bahsi geçen tüm özellikleriyle öykü, modernizmden öte postmodernizm izleri taşır. Gerek türlerarası, metinlerarası göstergeleri barındırıp çoklu bir metin oluşturması gerek anlatı tarzında polifonik bir sese imkân tanımasıyla öykü türünün yeni denemelerini sunduğu açıktır. Anlatının bileşenlerinin küçük aralıklarla sık sık değişmesi ise öykünün ritmini hızlandırmış ve durağan bir başlangıçla açılan öyküyü yerinde saydırmayıp metnin canlı bir okuma deneyimi sunmasına olanak tanımıştır. Metni yeni deneyimlere yaklaştıran bir diğer nokta da bahsi geçen masallarla birlikte kimi büyülü gerçekçi denilebilecek unsurlara yer vermesidir. Köle olmaktan, tabi olmaktan yılan karakter, ataerkil düzen 
içinden özgürlüğe kaçışın "anne"si ile mümkün olacağına inanır. Bu kurtuluş sahnesinin tasviri ise şu şekilde yapılır:

"Sokağa çıkıyor sesin ardından. Bu ses, bu çağrı, ona hiç görmediği ama bir gün kavuşmaktan asla vazgeçmediği anasını anımsatıyor: mavi saçlı, mavi giysili, saçlarını mavi bir kuleden sarkıtıp bir gün eninde sonunda onu yukarılara, maviliğe çekecek anasını [...] bir düşte kayarcasına buluyor köyün yolunu. Ama tutunduğu et ve barut parçaları, aşağılara çekiyor. Anasının mavi alnını bir gök parçasında görür gibi oluyor." (89).

"Saçların kuleden sarkıtılması" bir başka masala, Rapunzel'e işaret ederken karakterin bir düş içinde, büyü içinde özgürlüğünü kazanmasının anlatıldığı yukarıdaki satırlar, yer yer tekinsizliğiyle, yer yer doğaüstü olayları, tasvirleri içermesiyle büyülü gerçekçiliği andırır. Mavi rengin bu denli tekrarı ise yine özgürlüğün imleyicisi olarak umuda, kurtuluşa delalet eder. Mavilik anıştırmalarına rağmen karakteri aşağıya çeken unsurlar ağırlık gösterir ve anlatı,bir intihar sahnesi ile kapanır.

\section{Sonuç}

Tomris Uyar'ın öykücülüğünün ikinci evresine eklemlenebilecek “Düşkırıc1” isimli öykü, ontolojik kaygıların beslediği tutunamama/aidiyetsizlik temini işler. Hürriyetten yoksun bırakılan karakter, bu yönüyle masal kahramanları Çizmeli Kedi ve Pinokyo ile özdeşleştirilmiştir. Bir efendiye ait olma ya da bir efendinin kişiye sahip olması, hatta başlı başına bir "efendi" nin varlığı bireyi düşlerinden, benliğinden sıyırmıştır. Böylece yazar, yüzyıllar boyu anlatılagelen masallara, aktarılagelen anlatılara ve yazılagelen metinlere alternatif bir bakış üretir. Sözlü/geleneksel anlatı türlerine ait çeşitli arketipler güncel meseleler etrafında yeniden yorumlama/yazma edimiyle kaleme alınmıştır. Bu bağlamda geçmiş kültür ve birikimin modern bir görünümle yeniden sunulduğunu söylemek mümkündür. Tomris Uyar, eğlenilen, gülüp geçilen masal kahramanlarını aktüel zamana taşıyarak onların nasıl bir sancı içine düştüklerini/düşebileceklerini ironi yoluyla gösterir. Masalın büyülü atmosferinden kahramanları da okuru da çekip alan yazar, güncel döneme ait varoluşsal bir sorunsalı çarpıcı bir şekilde işler.

Öyküyü çarpıcı hâle getiren anlatının bileşenleridir. Masal anıştırmaları, tekerlemeler çok seslilik sağlarken iç monolog, montaj, serbest dolaylı anlatım gibi teknikler ise anlatıya çok yönlü bir boyut kazandırır. Teatral etkiyi artıran bu etkenlere anlatımlı, dramatik sahne, tablo gibi anlatı birimlerinin peş peşe verilmesi de eklenince öykü ritmik bir yapı kazanır.

Anlatı bilim ışığında incelenmeye çalışılan öykü, gerek düzeni gerek bakış açısı gerek de odaklanma yöntemiyle modernden öte postmodern bir anlatıdır. İçerik itibarıyla döneminin sancılarını yansıtan anlatı, biçim olarak da bu güncelliği yakalamıştır. 


\section{Kaynakça}

Boratav, Pertev Naili (1992). Zaman Zaman İçinde (2. Basım). İstanbul: Adam Yayınları.

Boratav, Pertev Naili (2000). Tekerleme. İstanbul: Türkiye Ekonomik ve Toplumsal Tarih Vakfi.

İleri, Selim (2008). “Türk Öykücülüğünün Genel Çizgileri.”Türk Dili Dergisi Türk Öykücüllü̆g̈u Özel Sayısı (2. Basım).Sayı 286.(2-29).Ankara: Türk Dil Kurumu Yayınları.

Nazik, Ayşegül (2001). Tomris Uyar Öykücülü̈̆̈̈̈nde Toplumsal Güncellik ve Biçimsel Arayışlar. Yayımlanmamış Yüksek Lisans Tezi. Ankara: BilkentÜniversitesi.

Necatigil, Behçet (1983). Edebiyatımızda İsimler Sözlüğ̈̈ (11. Basım). İstanbul: Varlık Yayınları.

Uyar, Tomris (2016). Gecegezen Kızlar (5. Basım). İstanbul: Yapı Kredi Yayınları.

Yivli, Oktay (2015). Kısa Öyküde Yöntem: Cemil Süleyman Uygulaması.Konya: Çizgi Kitabevi.

Yivli, Oktay (2016). “Ethem Baran'ın ‘Emanet Gölgeler Defteri'nde Temel Sorunsallar.” Yeni Türk Edebiyatı Dergisi. Sayı 14. (163-167). 